\title{
The Cosmology of Cognitive Science from Hesiod, Socrates, and Plato to Wittgenstein
}

\author{
By Richard McDonough*
}

\begin{abstract}
Cognitive science, the attempt to provide an account of human intelligence and behavior by reference to physical "mechanisms" in the alleged neural control center of human beings, is one of the dominant philosophical projects of our time. The paper argues that Wittgenstein in para. 608 of Zettel develops an alternative to this almost universally accepted modern paradigm. However, his efforts have been widely misunderstood, in a fashion clarified by Kuhn, because scholars read competing paradigms in the light of their own cognitive science paradigm. In the present case, scholars have assumed that the words in Zettel (para. 608), especially "the center" and "chaos," must have the same meanings that they would naturally be assigned in cognitive science. The result is, inevitably, that Zettel (para. 608) either looks like it anticipates one of the various cognitive science paradigms or it looks absurd. In opposition to this, the paper argues that the language in Zettel (para. 608) is not the language of modern cognitive science, but, rather, is the language of the emergence of order from chaos by virtue of a stabilizing center with which the Western intellectual tradition began in ancient Greek cosmology. When read against this background, it becomes clear that Zettel (para. 608) is an attempt to formulates an alternative to the cognitive science paradigm by retrieving a paradigm found in ancient Greek philosophy and literature. The idea that the brain is not the control center of the human organism is in Plato. The idea that the order in language and thought may arise out of "chaos" is prefigured in Hesiod. It is also argued that the core spirit of Wittgenstein's later philosophy is summed up in the ancient Socratic virtue, for which there is no precise modern equivalent, of sophrosyne. The "new" alternative to the paradigms of modern cognitive science that Wittgenstein sketches in Zettel (para. 608) is rooted in ancient Greek paradigms for thinking about the cosmos - and the human microcosm.
\end{abstract}

\section{The Cosmology of Cognitive Science from Hesiod, Socrates, and Plato to Wittgenstein}

[The Greek Masters from Thales to Socrates] invented ... the archetypes of philosophic thought. All posterity has not made an essential contribution to them since. Nietzsche, Philosophy in the Tragic Age of the Greeks (31) ${ }^{1}$

"Cognitive science" is, arguably, one of the dominant philosophical projects of our time. As the heir to the $18^{\text {th }}$ century Enlightenment project to realize the

*Retired, Adjunct, Arium School of Arts and Social Sciences, Singapore.

1. Friedrich Nietzsche, Philosophy in the Tragic Age of the Greeks, trans. Marianne Cowan (Chicago: Henry Regnery, 1969), 31. 
vision of $l$ 'homme Machine, it purports to provide an account of human intelligence and behavior by reference to physical or material "mechanisms" at the human neural center. ${ }^{2}$ Many scholars are certain this project is correct. Patricia Churchland claims that the only alternative to this mechanistic view is "magic." 3 Similarly, Colin McGinn states that there "just has to be" some mechanistic explanation of the way brains "subserve" minds. ${ }^{4}$ To be sure, there have been objections to this program by philosophers like Heidegger and Wittgenstein, but they are, admittedly, obscure. ${ }^{5}$ Kuhn teaches that establishment science is extremely resistant to the development of alternative paradigms, even invoking purely " $a d$ hoc" ways of saving the favored paradigms. ${ }^{6}$ Is it even possible to develop a genuine alternative to this near universally accepted materialistic and mechanistic cognitive science paradigm? What would an attempt to do so look like? The present paper follows Heidegger's suggestion that if one is to produce fundamental new ways of thinking, one must repeat the beginnings of philosophy, which means its beginnings in ancient Greece, in order to "reawaken" the possibilities there that have been lost to subsequent ages. ${ }^{7}$ The main text for the paper is para. 608 of Wittgenstein's Zettel. ${ }^{8}$ This passage from Wittgenstein's "later philosophy" has generally been claimed to say that language and thought may arise from physical chaos at the neural center. ${ }^{9}$ In order to show that this is

2. Richard McDonough, "Wittgenstein and the Possibility of a Science of Man," Idealistic Studies, Wittgenstein and Cognitive Science, ed. Richard McDonough. 29, no. 3 (1999): 125-26

3. Patricia Churchland, Neurophilosophy (Cambridge: MIT Press, 1989), 461-462.

4. Colin McGinn, Wittgenstein on Meaning (Oxford: Blackwell, 1984), 353. In general, philosopher's claim that something "just has" to be a certain way when they can find no actual evidence it is that way.

5. Richard McDonough, Martin Heidegger's Being and Time (New York: Peter Lang, 2006); Richard McDonough, "Towards a non-Mechanistic Theory of Meaning," MIND XCVIII no. 389 (1989), 1-21; Richard McDonough, "Bringing Cognitive Science Back to Life," in Wittgenstein and Cognitive Science, ed. Richard McDonough, Idealistic Studies, Special Issue. 29, no. 3 (1999b), 173-213; Richard McDonough, "Bringing Consciousness Back to Life". Metascience. 9, no. 2 (2000): 238-245; Richard McDonough, Review of Jerry Fodor, The Mind doesn't Work that Way, in Metascience. 10, no. 3 (2001).

6. Thomas Kuhn, The Structure of Scientific Revolutions (Chicago: University of Chicago Press, 1970): 77-91.

7. Rudgier Safranski, Martin Heidegger: Between Good and Evil, trans. Edward Osers (Cambridge, Mass: Harvard University Press, 1999), 246, 278.

8. Ludwig Wittgenstein, Zettel, trans. G.E.M. Anscombe (Berkeley: University of California Press, 1970).

9. By "Wittgenstein's later philosophy "is here meant the Blue and Brown Books, Philosophical Investigations, Zettel, Remarks on the Foundations of Mathematics, On Certainty, and the remarks in Culture and Value cited here. References to the Blue and Brown Books and Culture and Value are by page number, to Philosophical Investigations by paragraph number 
wrong, and that Zettel (para. 608) is proposing a radically "new" paradigm for thinking about language and mind, the paper argues that the language in Zettel (para. 608) is not the language of modern science, but, rather, is the literary religious-cosmological language of the emergence of a cosmos from chaos with which the Western intellectual tradition began in Hesiod and Plato. Call this the "Religious-Cosmological Interpretation" of Zettel (para. 608). ${ }^{10}$ The paper distinguishes Hesiod's and Plato's models of the sense in which the cosmos arises from chaos. This includes a discussion of Plato's microcosmic doctrine because it is this doctrine that licenses the application of cosmological models to human beings in order to produce the framework for modern cognitive science. The paper argues that modern mechanistic cognitive science is an application of a stunted interpretation of Plato's cosmology to the human microcosm, but that Zettel (para. 608) makes a novel application of these ancient cosmological models to human beings in order to propose a "new" paradigm for thinking about language and thought. This new paradigm has some affinities with Plato's cosmology, but also, in a different respect, with Hesiod's cosmology and with certain of Socrates' views.

The first part of the paper describes the core of the modern program of cognitive science. The second shows why the orthodox interpretations of Zettel (para. 608) cannot be correct. The third briefly sketches the "religiouscosmological" interpretation of Zettel (para. 608). The fourth explains Plato's relevant cosmological and microcosmic doctrines. The fifth discusses the cosmological model that provides the foundation for cognitive science and shows how the ancient microcosmic doctrine reappears in one highly influential version of cognitive science. The sixth shows how Hesiod's, Plato's and Socrates' views enable one better to appreciate the "new" paradigm Wittgenstein proposes in Zettel (para. 608). Finally, the last part explains why Wittgenstein's real program in Zettel (para. 608) has proved so elusive to modern philosophers.

or page number as required, to Zettel and On Certainty by paragraph number, to Remarks on the Foundations of Mathematics by section and paragraph number.

10. Richard McDonough, "Wittgenstein's Zettel 608: An Analogy with Martin Buber," Iyyun 63 (July) (2014): 259-288; Richard McDonough, "Wittgenstein from a Religious Point of View?" Journal for the Study of Religions and Ideologies, 15 no. 43 (2016): 3-27. 


\title{
The Basic Program of Cognitive Science
}

\begin{abstract}
The central nervous system is composed of the brain and spinal cord and can be thought of as the control center for interpreting sensory input and directing our thoughts and actions. Stillings, Chase and Feinstein, Cognitive Science: An Introduction ${ }^{11}$
\end{abstract}

There are three main paradigms in Cognitive science, the "representational theory of mind," defended by Jerry Fodor, ${ }^{12}$ connectionism, defended by P.S. Churchland, P.M. Churchland and Steven Stich, ${ }^{13}$ and dynamic systems theory, defended by Port and Van Gelder. ${ }^{14}$ Despite the differences between these paradigms, all agree that mind and intelligence are realized in the brain. Fodor holds that information is available to an organism when it is "encoded" in causally effective neural states. ${ }^{15}$ P.S. Churchland, apparently believing that there is no distinction to be made between the personal and the sub-personal level, does not ask how Susan visually recognizes shapes but how her brain does recognizes them. ${ }^{16}$ Port and Van Gelder claim that "the [self-organizing] brain may achieve autonomous control [of perception and behavior] in a rapidly changing environment." 17 All three of these paradigms agree with the basic

11. Neil Stillings, Christopher Chase and Mark Feinstein, Cognitive Science: An Introduction (Cambridge: MIT Press, 1995), 271.

12. Jerry Fodor, The Language of Thought (Cambridge: Harvard, 1979); Jerry Fodor, Psychosemantics (Cambridge: MIT Press, 1987); Jerry Fodor, LOT 2 (Oxford: Oxford University Press, 2020).

13. Patricia Churchland, Neurophilosophy. Paul Churchland, A Neurocomputational Perspective: The Nature of Mind and the Structure of Science (Cambridge: MIT Press, 1989); Paul Churchland, The Engine of Reason, the Seat of the Soul: A Philosophical Journey into the Brain (Cambridge: MIT, 1995). Steven Stich, From Folk Psychology to Cognitive Science: The Case Against Belief (Cambridge, Mass: MIT Press, 1983). For those not familiar with the precise terminology in "cognitive science," note that whereas in Fodor's "Representational Theory of Mind," information is encoded in the brain in discrete states, but in the "connectionist" model, defended by the two Churchland's, Stich and others, information is "distributed holistically" over the entire "neural net," not encoded in any discrete state. See P.M. Churchland, The Engine of Reason, 47 and Ho, Edward Kei Sjhin and Chan, Kei Lan, "How to Design a Connectionist Holistic Parser," Neural Computation, 11 no. 8 (1999): 1995-2016! For arguments against connectionism see Richard McDonough, "A Culturalist Account of Folk Psychology," in The Future of Folk Psychology: Intentionality and Cognitive Science, ed. John Greenwood (Cambridge: Cambridge University Press, 1991) and Richard McDonough, Review of Paul Churchland, The Engine of Reason, the Seat of the Soul, Metascience 7, no. 2 (1998): 374-380.

14. Robert Port, and Timothy Van Gelder, Mind as Motion: Explorations in the Dynamics of Cognition (Cambridge: MIT, 1995).

15. Fodor, Language of Thought, 52

16. Patricia Churchland, Neurophilosophy, 239.

17. Port and Van Gelder, Mind as Motion, 450 
tenant of Cognitive science that the brain is the central control system of human language, thought and behavior.

Richard Green points out that "central state materialism" involves two subtheses, first, the "identity theory," the view that mental states are identical with brain states, and, second, the view that the brain works like a machine, in which brain states are correlated with mental states, that obeys the principles of physics and chemistry. ${ }^{18}$ The present paper is not concerned with the strong "identity thesis," but only with the more moderate mechanistic thesis of central state materialism because, as Putnam points out, the identity thesis is considered controversial, but "everyone knows that there is at least a correlation" between mental states and states of the brain. ${ }^{19}$ The machine model is ubiquitous in cognitive science. Fodor states that "I shall continue to rely heavily on the machine analogy." 20 P.S. Churchland states that "If you root yourself in the ground [i.e., plants], you can afford to be stupid. But if you move [i.e., animals], you must have mechanisms for moving." 21 Port and Van Gelder (purport to describe the exotic cognitive "mechanisms" posited by "mathematical dynamical systems" theory. ${ }^{22}$ Despite various differences, all versions of cognitive science agree that human intelligence and behavior are produced by this physical machine at the cranial or neural center. ${ }^{23}$ But is it really obvious than that some version of this of nearly universally accepted materialistic mechanistic paradigm is correct - or is it the case that the inability to envision alternatives is either a failure of imagination or a failure to know our own history tracing to the Ancient Greeks?

\section{The Orthodox Interpretation of Zettel (608)}

No supposition seems to me more natural than that there is no process in the brain correlated with associating or with thinking; so that it would be impossible to read off thought processes from brain processes. I mean this: if I talk or write, there is, I assume, a system of impulses going out from my brain and correlated with my spoken or written thoughts. But why should the system continue further in the direction of the center? Why should this order not proceed, so to speak, out of chaos? Wittgenstein, Zettel (608). ${ }^{24}$

18. Richard H. Green, "Central State Materialism and Consciousness," Philosophy 56, no. 215 (1981): 106

19. Putnam is here being sarcastic since his whole point in this passage is that this confidence is misplaced.

20. Fodor, Language of Thought, 68.

21. Patricia Churchland, Neurophilosophy, 13

22. Port and Van Gelder, Mind as Motion, $559 \mathrm{ff}$

23. Susan Greenfield, Journey to the Centers of the Mind (New York: W.H. Freeman and Co., 1995), 24-56.

24. Wittgenstein, Zettel, para. 608. 
Zettel (para. 608) is a striking passage, especially for the anti-metaphysical philosopher Wittgenstein. ${ }^{25}$ For it has been interpreted to say that language and thought may arise from chaos in the brain. Call this the "neurological interpretation" of Zettel (para. 608)! Colin McGinn thinks Zettel (para. 608) states that normal human heads might turn out to be filled with sawdust; Richard Scheer believes it suggests that causal indeterminism may occur in the brain; Martin Davies, Stephen Mills and John Sutton separately claim it anticipates recent "connectionist" models of neural processing; Hanoch Ben-Yami thinks it holds that it is possible that the brains of normal people might be in physical chaos; Ter Hark thinks it suggests an alternative to Köhler's theory of electric brain-fields. ${ }^{26}$ But all agree that the "center" and "chaos" mentioned in Zettel (para. 608) are the neural center and neural chaos. Thus, all hold that Zettel (para. 608) suggests that language may arise out of physical chaos in the brain. Since the case against the neurological interpretation has been made in detail elsewhere only the most basic points are repeated here. ${ }^{27}$

The first obvious problem with the neurological interpretation is that Zettel (para. 608) explicitly denies that the brain is in chaos. The second sentence of the passage affirms that "there is, I assume, a system [LW's emphasis] of impulses going out from my brain and correlated with my spoken or written thoughts." Indeed, the neurological interpretation has to be wrong here because it is a basic tenant in Wittgenstein's later philosophy is that "what is hidden is of no interest to us" and that, therefore, "we must not advance any kind of theory," ${ }^{28}$ which includes theories about sawdust in the head, connectionist processing, quantum

25. Wittgenstein, Philosophical Investigations, para. 116.

26. McGinn, Wittgenstein on Meaning, 12-13, 112-114; Richard Scheer, “Wittgenstein's Indeterminism," Philosophy. 66, no. 255 (1991): 5-23; Martin Davies, "Concepts, Connectionism, and the Language of Thought," in Philosophy and Connectionist Theory, ed. Ramsey, Stich, Rummelhart (Hillsdale: Psychology Press, 1991); Stephen Mills, "Wittgenstein and Connectionism," Philosophy and Cognitive Science, ed. Christopher Hookway and Donald Peterson (Cambridge University Press, 1993); John Sutton, "Remembering as Public Practice: Wittgenstein, Memory, and Distributed Cognitive Ecologies," Mind, Language and Action, ed. V.A. Munz and A. Coliva (Kirchberg am Wechsel, 2014); Hark, Ter. "Electric Brain Fields and Memory Traces: Wittgenstein and Gestalt Psychology," Philosophical Investigations 18 no. 2 (1995): 113-138; Hanoch Ben-Yami, "The Hercules in the Machine: Why Block's Argument against Behaviorism is Unsound," Philosophical Psychology 18, no 2 (2005): 179-286.

27. McDonough, "Towards a non-mechanistic theory"; McDonough, "A Culturalist Account"; Richard McDonough, "Wittgenstein, German Organicism, Chaos, and the Centre of Life," Journal of the History of Philosophy XLII, no. 3 (2004): 297-324; Richard McDonough, "Wittgenstein's Augustinian Cosmogony in Zettel 608," Philosophy and Literature 39, no. 1 (2014): 87-106; Richard McDonough, "A Gestalt Model of Zettel 608," Idealistic Studies 46, no. 2 (2016): 163-82 and Richard McDonough, "A Music Model of Zettel 608: Haydn and Beethoven," The Journal of Music and Meaning 14 (2018): 21-40.

28. Wittgenstein, Philosophical Investigations, para's 109, 435. 
indeterminacy in the brain, and Köhler's theory of electric brain fields. Indeed, at Zettel (para. 447), Wittgenstein states that his aim is to replace "wild conjectures and explanations by quiet weighing of linguistic facts." ${ }^{29}$ None of these extravagant theories invoked in the neurological interpretation remotely resembles "a quiet weighing of linguistic facts." The idea that in Zettel (para. 608) Wittgenstein has suddenly begun theorizing about hidden neural processes simply does not make sense.

The second obvious problem is that Zettel (para. 608) does not state that language and thought may arise out of chaos. It states that they may, "sozusagen [so to speak]" do so. Wittgenstein's later philosophy does not state theories but, rather, makes philosophically illuminating comparisons. ${ }^{30}$ Zettel (para. 608) compares the production of language with the emergence of order from chaos, but it does not assert any theory that language and thought might literally arise from chaos. There can be no emergentist theory, of the sort that one does finds in R.W. Sellars, in Zettel (para. 608). ${ }^{31}$

The third obvious problem is that Zettel (para. 608) does not say that the system of brain impulses continues towards the neural center. That is asserted by the neurological interpretation, but it is not stated in the text. If one reads Zettel (para. 608) closely, it is clear that the neural impulses are moving from the brain towards the center, which means that the "center" is in the external world, that is, in the same region as "my spoken or written thoughts." Wittgenstein's later philosophy explicitly identifies this center. Anscombe translates para. 108 of the Philosophical Investigations to say that Wittgenstein's later philosophy focusses on "the fixed point [Angelpunkt] of our real need," but the literal translation of "Angelpunkt" is "center-point." 32 Wittgenstein's later philosophy sees "ordinary life" as the true "center" around which language, sozusagen, turns. Wittgenstein's notion of the center of a language in his later philosophy is also explicitly identified in his Remarks on the Foundations of Mathematics as the notion of a lifephenomenon, not the notion of a neural phenomenon..$^{33}$ What could be clearer than that Wittgenstein's later philosophy holds that language is centered in ordinary life

29. Wittgenstein, Zettel, para. 447.

30. Wittgenstein, Philosophical Investigations, para's 130-131; Ludwig Wittgenstein, Remarks on the Foundations of Mathematics, trans. G.E.M. Anscombe (Cambridge: MIT Press, 1972), V.12; Ludwig Wittgenstein, Culture and Value, trans. Peter Winch (Chicago: University of Chicago, 1980), 19.

31. Richard McDonough, "Roy Wood Sellars," Internet Encyclopedia of Philosophy §’s 3 \& 4, http://www.iep.utm.edu/sella-rw/

32. Wittgenstein, Philosophical Investigations, para. 108; John Traupman, German E English Dictionary (New York: Bantam Books, 1991): 17.

33. Ludwig Wittgenstein, Remarks on the Foundations of Mathematics, §'s III. 15 and V.12 
rather than the brain? In the Philosophical Investigations, he asks, "Now ask yourself: what do you know about these things [in the brain]." 34

The single most significant scientific and philosophical advance in the past several thousand years is, arguably, the "Copernican Revolution" in astronomy, in which Copernicus replaces the entrenched Ptolemaic view that the earth is the center of the universe with his new view that the true center is the sun. What was thought to be the center, the earth, is reassigned to the periphery, and what was thought to be periphery, the sun, is identified as the true center. Zettel (para. 608) proposes its own "Copernican Revolution," not in astronomy, but in our views of language and thought. ${ }^{35}$ Whereas cognitive science holds that language and thought "revolve," sozusagen, around the central brain, Zettel (para. 608) suggests that they "revolve," sozusagen, around human activities in "forms of life." 36 Whereas cognitive science sees the brain as the control center of the organism, Wittgenstein's later philosophy, reflected in para. 608 of Zettel, sees the brain as a mere instrument employed by the human-organism-situated in-the-world. ${ }^{3737}$ Zettel (para. 608) does not deny that one needs a functioning brain to think. It only denies that our brain is the autonomous control center of human intelligence. Rather, Zettel (para. 608) suggests that the human organism is centered in their public world of human activities. It is, roughly, Susan-situated in-her-world, not the brain imprisoned inside her cranium, who decides what she thinks or means.

Wittgenstein's "Copernican" reversal on the identity of the true center also clarifies the nature of the "chaos" referenced in Zettel (para. 608). Since Wittgenstein's later philosophy identifies the center as human forms of life, and since the chaos is where the center is, Zettel (para. 608)'s point is that language and thought "emerge," sozusagen, from the chaos of activities in those "forms of life." 38 Indeed, Wittgenstein's later philosophy employs this chaos-imagery

34. Wittgenstein, Philosophical Investigations, para. 158.

35. McDonough, "Towards a non-mechanistic," 18-21; See also Ilham Dilman, Wittgenstein's Copernican Revolution: The Question of Linguistic Idealism (Basingstoke: Palgrave, 2002), 18-37.

36. Wittgenstein, Philosophical Investigations, 174, 226.

37. Richard McDonough, "The Last Stand of Mechanism," Journal of Speculative Philosophy 6, no. 3 (1992): 206-25, § V. The idea that an organism is properly conceived as "the-the-world," in something like Heidegger's sense, not in a cranial vat, is crucial here. On the notion of being-in-the-world, see Martin Heidegger, Being and Time, trans. John Macquarrie and Edward Robinson (San Francisco: Harper San Francisco, 1962), §’s 12-13! On the fallacies in the view that human beings might be brains in a vat, see Richard McDonough, "Putnam's Argument that the View that we are Brains-in-a-vat is SelfRefuting," Meta: Research in Hermeneutics, Phenomenology, and Practical Philosophy, 10, no. 1 (2018): 149-159.

38. McDonough's "A Gestalt Model" argues that the way an image of a dog "emerges" from the spots on the paper in Gestalt psychology offers a better model of the 
elsewhere. In Culture and Value, he suggests that philosophers must learn to make a home in "primeval chaos" - but there is nothing "primeval" about the brain and one cannot make a "home" in it. ${ }^{39}$ Wittgenstein's later philosophy also refers to this chaos in human life when he states that "what determines our judgment" about what something means is "the background" consisting of "the ganze Gewimmel [great swarm] of human actions." 40 Roughly, expression E means M if and only if $\mathrm{E}$ is part of a pattern that arises against the chaotic background "swarm" of human actions. That is why Wittgenstein that philosophizing requires a descent into the chaotic swarm of activities in human forms of life. This "descent" is required for the philosopher because in Wittgenstein's later philosophy, it is in these activities, not in processes in the brain, that linguistic meaning resides. Thus, Zettel (para. 608) does not say that language and thought may arise from chaos at the neural center. Rather, it suggests that language and thought arise, sozusagen (one cannot forget the "sozusagen_), from the "chaos" of human activities in the "Angelpunkt of our real need" (ordinary life). If Zettel (para. 608) had been written by a cognitive scientist, it might make sense that its references to the center and to chaos are properly understood as referring to the neural center and neural chaos, but this makes no sense for a philosopher among whose primary purposes is to criticize the materialistic mechanistic program of cognitive science. ${ }^{4141}$

\section{The Religious-Cosmological Interpretation of Zettel (608)}

Wittgenstein told] his close friend Drury: ... "I am not a religious man but I cannot help seeing every problem from a religious point of view."

Malcolm, Wittgenstein: From a Religious Point of View?42

kind of non-theoretical non-causal emergence Wittgenstein has in mind here. One literally can "see" the image of the dog "emerge" from the spots.

39. Ludwig Wittgenstein, Culture and Value, 65.

40. Wittgenstein, Zettel, para. 567.

41. Bruce Goldberg, "Mechanism and Meaning," in Knowledge and Mind: Philosophical Essays, edited by Carl Ginet and Sydney Shoemaker (Oxford: Oxford University Press, 1983); Bruce Goldberg, "Are Human Beings Mechanisms?" Idealistic Studies, Special Issue. Wittgenstein and Cognitive Science, ed. Richard McDonough 29 no. 3 (1999): 139-152; Norman Malcolm, Memory and Mind (Ithaca: Cornell University Press, 1977); Norman Malcolm and David Armstrong, Consciousness and Causality: A Debate on the Nature of Mind (Oxford: Blackwell, 1984); Norman Malcolm, Nothing is Hidden (Oxford: Blackwell, 1986); McDonough, "Towards a non-mechanistic theory"; McDonough, "A Culturalist Account," and McDonough, "Bringing Cognitive Science Back to Life," 173-213; D. Proudfoot, "On Wittgenstein on Cognitive Science. Philosophy 72, no. 280 (1997): 189-217; Peter Hacker and Max Bennett, Philosophical Foundations of Neuroscience (Blackwell: Oxford, 2003).

42. Norman Malcolm, Wittgenstein: From a Religious Point of View? (New York: Routledge, 1997), 1. 
One of the keys to understanding Zettel (para. 608) is the recognition that it is not speaking in the language of cognitive science, but, rather, in the literary religious-cosmological language of the creation of a cosmos from chaos with which the Western intellectual tradition began in Hesiod's Theogony and which was subsequently carried down through the entire Western cultural tradition. ${ }^{43}$ The ancient cosmological notions of the emergence of order from chaos at the center is found in a plethora of literary, religious, scientific and philosophical thinkers throughout the Western tradition. The language and imagery in Zettel (para. 608), the emergence of some kind of meaning from chaos at the center, is found, respectively, in Augustine and Buber, in Austrian economics, in Gestalt psychology, in Borges, in Wittgenstein's own "labyrinth" imagery, and in Haydn and Beethoven. ${ }^{44}$ Indeed, the key concepts in Zettel (para. 608), the emergence of a meaningful order from chaos at the center can be found in the cosmology in first few paragraphs of Milton's Paradise Lost and throughout the work and also in Goethe's Faust. ${ }^{45}$ In each of these areas, one finds various versions of the view that religious meaning (Augustine, Milton, Goethe, and Buber), economic meaning or value (Austrian economics), perceptual meaning (Gestalt psychology), and musical meaning (Haydn and Beethoven) arises out of the relevant kind of chaos by virtue of movement towards the relevant center. In Augustine, Milton and Buber, the relevant center is, roughly, God or human communion with God, and the relevant chaos is the moral chaos of fallen human life. In Austrian economics the relevant center is the market activity that forms the "center of gravity" of a free market economy and the chaos is the chaotic behavior of the market actors. In Gestalt psychology the relevant center is the stabilizing center of the visual field and the relevant chaos is the chaos of perceptions out of which the Gestalt-image arises. In Haydn and Beethoven, the relevant center is the tonal center of the musical piece and the relevant chaos is the dissonant sounds out of which the musical harmony arises by virtue of the movement towards that stabilizing tonal center. That is, each of these areas, religion, Austrian economics, Gestalt psychology, literature, and music is treated as a microcosm of the cosmos in which the relevant cosmic structure, the emergence of order from chaos by virtue of movement towards an order-producing center, is reproduced, with modifications due to the special requirements of the specific area. The religious-

43. Robert Lamberton, Introduction to Hesiod: Works $\mathcal{E}$ Days and Theogony (Indianapolis: Hackett, 1993).

44. Richard McDonough, "Wittgenstein's Augustinian Cosmogony" and Richard McDonough, "Wittgenstein's Zettel 608: An Analogy"; Richard McDonough, "Wittgenstein's Philosophy and Austrian Economics," Studies in the Sociology of Science 5 no. 4 (2014): 1-11; Richard McDonough, "A Gestalt Model." Richard McDonough, "Wittgenstein's and Borges Labyrinth Imagery," The Athens Journal of Humanities and the Arts (2018); and Richard McDonough, "A Music Model."

45. Richard McDonough, "Philosophy in a Fallen Language: Wittgenstein, Goethe, Milton," Studies in Language and Literature 10, no. 4 (2015): 1-14. 
cosmological interpretation of Zettel (para. 608) holds that the cosmological model developed in ancient Greece reappears in these and other areas of the Western intellectual and cultural traditions. Zettel (para. 608) simply applies the cosmological model implicit in all of these diverse areas to the cases of language and mind. The religious-cosmological interpretation does not claim that Zettel (para. 608) is advancing cosmological theories about language and thought, but, rather, that it compares the genesis of language and thought to the genesis of the cosmos in order to shed light on the natures of language and thought. There is no need to repeat the specific arguments here since the next section develops the argument in connection at one of its primal sources: Plato.

\section{The Emergence of Order from Chaos at the Center in Plato's Cosmology}

Wherefore finding the whole visible sphere ... moving in an irregular and disorderly fashion, out of disorder [God] brought order ... [so that] the world came into being, a living creature ... [God] made [the cosmos] ....in every direction equidistant from the center [where] he put the soul, .... [W] hen the creator had framed the soul according to his will, he formed within her the corporeal universe ... and united them center to

center.

Timaeus (30a-c, 34a-b, 36d-e51) $)^{46}$

Whitehead suggests that "the European philosophical tradition ... consists in a series of footnotes to Plato." 47 However, if the views in the previous section are correct, there is a sense in which the entire Western intellectual and cultural tradition, not just the philosophical tradition, consists in a series of footnotes to Plato. For the cosmological model articulated by Plato reappears repeatedly not just in philosophy, but in religion, literature, economics, psychology, music and other areas. The present section discusses Plato's cosmology with a view to illuminating Wittgenstein's real method and aims in Zettel (para. 608).

Plato's Timaeus describes the cosmos as a living organism created by God, the "Demiurge," who follows "eternal patterns" (which resemble Plato's "Forms"). ${ }^{48}$

46. Plato, Timaeus, The Collected Dialogues of Plato, ed. Edith Hamilton and Hamilton and Huntington Cairns (Princeton: Princeton University Press, 1969): 30a-c, 34a-b, 36d-e51. McDonough elsewhere contrasts Plato's organicism with the very different species of organicism in Taoist philosophy. See Richard McDonough, "Plato's Cosmic Animal vs the Daoist Cosmic Plant," Journal for the Study of Religions and Ideologies, 15 no 45 (2016): 1-22. McDonough also discusses the surprising unexpected remnants of Plato's organism in Wittgenstein's Tractatus. See Richard McDonough, "The Unspeakable Organicism in Wittgenstein's Tractatus," Iyyun 66 no. 1 (2017): 1-17.

47. A.N. Whitehead, Process and Reality: An Essay in Cosmology (corrected edition) (New York: Free Press, 1978), 39.

48. Gabriela Roxana Carone, Plato's Cosmology and its Ethical Dimensions (Cambridge: Cambridge University Press, 2005): 69ff; For a definition and taxonomy of the various 
Unlike the Christian God, who creates ex nihilo, Plato's Demiurge, like a craftsman, fashions the cosmos out of pre-existing materials. ${ }^{49}$ For Plato, the creation consists in putting "intelligence in soul and soul in body" according to the eternal patterns, where the soul as the source of life and principle of self-motion. ${ }^{50}$

Alluding to Hesiod's view that the cosmos arises from chaos, Plato describes the pre-existing materials as "disordered," but by this Plato does not mean the complete absence of order. Vlastos points out that Plato thinks of mechanism as disorderly, [unless] it is teleologically ordered." ${ }^{51}$ Thus, Plato would see a thoroughly Newtonian world unguided by rational purpose as chaotic. Thus, Plato's view that the cosmic organism arises out of chaos is consistent with its arising out of a mechanical order. That is, Plato's God, the Demiurge, is "a divine mechanic," but, as Vlastos also points out, not merely a divine mechanic. ${ }^{22}$ This extremely important if one is to understand the origins of the modern mechanistic cognitive science paradigm as another "footnote" to Plato's cosmology.

The pre-existing chaotic materials take the form of a sphere, but it turns out that a sphere is also the most rational shape for the cosmic organism created out of that pre-existing chaos. The Demiurge imposes an order on that pre-existing chaotic visible sphere that makes it suitable to house the soul. One could not install a rational soul into a chair. A being must have a complex body and brain if it is to be capable of housing a soul. Thus, Plato does not deny that there are material or mechanical conditions for life and mind. In fact, he insists that there are such conditions. He only holds that these are subordinate to the teleological concerns of sovereign reason..$^{53}$

Plato's view that the Demiurge synchronizes the pre-existing "visible sphere" and the spherical cosmic organism "center to center" means that it makes the mechanical and mental dimensions of the organism harmonize with each other.

notions of organism, see Richard McDonough, "Organicism," Dictionary of the Philosophy of Mind. (2016), https://sites.google.com/site/minddict/organicism.

49. Wilfrid Sellars, "The Soul as Craftsman," in Philosophical Perspectives (Springfield: Charles C. Thomas Publisher, 1967); F.M. Cornford, Plato's Cosmology, (London: Routledge Kegan Paul, 1997): 37, 173, 176.

50. Plato, Phaedo, trans. Hugh Tredennick. The Collected Dialogues of Plato, ed. Edith Hamilton and Hamilton and Huntington Cairns (Princeton: Princeton University Press, 1969), 105c; Plato, Phaedrus, trans. R. Hackforth, The Collected Dialogues of Plato. Ed's. Edith Hamilton and Hamilton and Huntington Cairns (Princeton: Princeton University Press, 1969): 245c; Plato, Timaeus, 30a-c; Plato. Laws, trans. A.E. Taylor. The Collected Dialogues of Plato. Ed's. Edith Hamilton and Hamilton and Huntington Cairns (Princeton: Princeton University Press, 1969): 896a, 966e.

51. Gregory Vlastos, "The Disorderly Motion of the Timaeus," in Studies in Plato's Metaphysics, ed. R.E. Allen (London: Routledge and Kegal Paul, 1968): 398 \& n 2.

52. Gregory Vlastos, Plato's Universe (Seattle: University of Washington Press, 1975), 27.

53. Vlastos, "The Disorderly Motion," 397-8. 
In doing so, Plato formulates an early version of the "correlation thesis," 54 the view that there must be a correlation between the mental and material states of the organism. Thus, the world-organism possesses an organic unity by virtue of its central order-imposing soul. Since there is nothing outside the cosmic organism, and since it is controlled by its own soul, it is autonomous in the visible (material) world. It does depend on the eternal Forms, which are the ultimate causes of its being, ${ }^{55}$ but it does not depend on anything more basic within the visible world.

Unlike Pythagoras, who anticipated Copernicus' view that the earth is a planet that moves around the central fire. ${ }^{56}$ Plato holds that the earth is at the center of the cosmos and that the heavens revolve around it. It is significant that the center of the sphere is more chaotic than the heavens at the cosmic periphery: Although Plato states that the earth is "as pure as the starry heavens," he adds that "the earth" and "the regions in which we live are marred and corroded just as in the sea everything is corroded by the brine." ${ }^{57}$ For example, animals on earth move in a haphazard fashion, while the heavenly bodies move in near perfect circles. This is because the movements at the periphery of the cosmos in the heavens better reflect the perfectly rational Forms, ${ }^{58}$ the true causes of what is, while the earth, at the imperfect center of the cosmic sphere, is fraught with chaos and imperfection. ${ }^{59}$

54. Putnam, Hilary. Reason, Truth and History (Cambridge: Cambridge University Press, 1981): 81

55. Plato, Republic, 509b; Timaeus 30b-c, 90c.

56. John Mansley Robinson, An Introduction to Early Greek Philosophy (Boston: Houghton Mifflin, 1968), 76.

57. Phaedo, 109e-110a.

58. Plato, Timaeus, 28a-b, 39d.

59. Plato, Statesman, 273b-c; Plato, in a stirring passage, has Phaedrus, in the Symposium refer to Hesiod's account of the god Chaos, but Plato is generally highly critical of Hesiod. Plato, Symposium, trans. Michael Joyce, The Collected Dialogues of Plato, ed. Edith Hamilton and Hamilton and Huntington Cairns (Princeton: Princeton University Press, 1969): 178b. Protagoras, in Plato's Protagoras, describes Hesiod as a Sophist in disguise. Plato, Protagoras, trans. W.K.C. Guthrie, The Collected Dialogues of Plato, ed. Edith Hamilton and Hamilton and Huntington Cairns (Princeton: Princeton University Press, 1969), 316d. Socrates, in the Republic, states that Hesiod's stories are not appropriate for children. Plato, Republic, 377d. In the Epinomis, Hesiod's astronomy is criticized on the grounds that it is merely observational and does not make sufficient use of mathematics. Plato, Epinomis, trans, A.E. Taylor, The Collected Dialogues of Plato. Edited by Edith Hamilton and Hamilton and Huntington Cairns (Princeton: Princeton University Press, 1969), 990a. Since Plato holds that true philosophy searches always for the unchanging order underlying the apparent chaos, Plato sees Hesiod's sort of view that emphasizes the inherent chaos in the cosmic organism as inherently unphilosophical. A word is required about the reference to the Epinomis. Although the Epinomis is generally believed to have been authored by one of Plato's disciples, not by Plato himself, it is believed to represent the "spirit" of Plato's 
Plato's microcosmic doctrine is his view that mortal organisms are copies, although imperfect ones, of the cosmic organism. ${ }^{60}$ Since an ordinary mortal organism, like a human being, is a microcosm of the whole cosmos, the structure of a mortal organism, like a human being, parallels that of the macrocosm. Just as the cosmos is a sphere that contains a "chaotic" mechanism at the imperfect earthly center, the human head is a sphere that contains a, so to speak, "chaotic" mechanism, the brain, at its imperfect center. However, although Plato acknowledges that the neural mechanism at the center of the head is important, he holds that the true final causes (telos) of human behavior are reflected at the periphery of the cosmos in the heavens, for the perfect mathematical motions in the heavens mirrors the perfect unchanging eternal Forms that are the true ultimate cause of all existence. ${ }^{61}$

In summary, Plato's Timaeus holds that the earth is at the center of a unique cosmic organism, in whose image human beings have been created, and whose nature and destiny has been ordained by eternal perfect unchanging causes. The night sky does not merely display physical bodies moving mindlessly in accord with blind mechanical laws. ${ }^{62}$ Rather, it is the display of the radiant periphery of that perfect cosmic life, the image of our own better selves, from which we, mostly unknowingly, unless we achieve the required wisdom, draw our being and our destiny. Plato does not deny that the brain is involved in human behavior. What he denies is that it is the control center of human beings. The true "cause" of human behavior is not the machine between the ears, but is outside the human being, reflected in the celestial periphery of the cosmos, whose more perfect motions better reflect the perfection of the perfect eternal Forms. Plato does not, therefore, subscribe to cognitive science's "central state materialism." Indeed, the Timaeus makes clear that materialism cannot account for what takes place in the world..$^{63}$

views. See John Cooper, (ed.), Plato: Complete Works (Indianapolis: Hackett, 1997), 1617. Cooper goes on to say that the Epinomis gives a "selective and distorting emphasis" to various elements of Plato's view, such as its view that "wisdom is constituted solely by knowledge of astronomy," but the present paper only requires that astronomy is an element in Platonic wisdom, not that it is the "sole" repository of Platonic wisdom. See also Richard McDonough, "Plato: Organicism," Internet Encyclopedia of Philosophy, § 2.a, http://www.iep.utm.edu/platoorg/.

60. McDonough, "Plato's Organicism," § 2.b; Carone, Plato's Cosmology, 30, 98, 161.

61. Allen Silverman, "Plato's Middle Period Metaphysics and Epistemology," Stanford Encyclopedia of Philosophy (2014), §13, https://plato.stanford.edu/entries/plato-metaphysics.

62. Plato, Epinomis, 982e-983a. Recall the qualification about the Epinomis and its consilience with Plato's views in note 59 above.

63. Cairns, Huntington, Introduction to the Charmides. The Collected Dialogues of Plato, ed. Edith Hamilton and Huntington Cairns (Princeton: Princeton University Press, 1969): xxv. McDonough, "Plato's not to Blame." 


\section{The Cosmology of Cognitive Science}

It follows ... that not all languages one knows are languages one has learned, and that at least one of the languages one knows without learning is as powerful as any language one can ever learn. I admit that these conclusions may really seem scandalous. Fodor, The Language of Thought 64

The basic framework of modern cognitive science is implicit in Plato's cosmology and his associated microcosmic doctrine, which is not to say that Plato endorses anything remotely like modern materialist mechanistic cognitive science. Rather, the core framework of cognitive science is just one more of those many "footnotes to Plato". It is present in Plato's cosmology somewhat as the statue is present in the stone (where one must destroy the stone to get the statue). The present section shows, first, how the place for the cognitive science framework is prepared in Plato's views, and second, how the ancient microcosmic doctrine appears in one highly influential modern version of cognitive science, Fodor's "language of thought" doctrine.

The core cognitive science framework can be found in Plato's cosmological views by excising certain key parts of Plato's views. Recall, first, that Plato held that the cosmic organism is created by "uniting" the corporeal (material mechanical) sphere and the sphere of the cosmic organism "center to center" (a metaphorical way of saying that the material and the spiritual dimensions of the organism must work harmoniously together). Recall also that he holds that the center of the cosmic organism, the earth, is "chaotic," but this is consistent with the existence of some kind of mechanism there. Recall also that, given Plato's microcosmic doctrine, and his view that the brain is the seat of human intelligence, Plato also agrees that there is a mechanism of some kind at the neural center that underlies human intelligence. But he also holds that the mechanical causes operative at the neural center are profoundly dependent on the more basic causes at the cosmic periphery (which latter better reflect Plato's eternal final causes). Thus, if one eliminates Plato's final causes at the cosmic periphery, which are, in the $20^{\text {th }}$ and $21^{\text {st }}$ centuries, largely seen as metaphysical superstitions, one is left with the material mechanical causes at the cosmic center, and, via Plato's microcosmic doctrine, one is left with the material mechanical causes at the neural center of the human microcosm. That is, cognitive science's framework of the controlling central state neural machine is derived from Plato's cosmology by eliminating the final causes, which are the most fundamental causes for Plato, from both the cosmos and from the microcosm, the human being, modelled on it. This truncated picture of the human organism, stripped of the primary and most fundamental causes in Plato's cosmology and microcosmic doctrine, provides the

64. Fodor, The Language of Thought, 82. 
core model for cognitive science. One might put this somewhat bluntly, by saying that one obtains the core paradigm of modern mechanistic cognitive science by starting with Plato's view of the human microcosm and denuding it of everything that is of "ideal" or "spiritual" importance.

It is also useful to show how Plato's microcosmic doctrine appears in one of the seminal views in modern cognitive science, Fodor's "language of thought" doctrine. ${ }^{65}$ Since Plato's microcosmic doctrine holds that mortal organisms are miniature copies of the cosmic organism, he holds that the human organism can think about the cosmos only if its brain imitates the motions of the heavens. It is true that, for Plato, the human brain, at the chaotic center, only imitates those heavenly motions imperfectly, but that explains why human beings do not think about the cosmos perfectly accurately. Plato holds that humans can only think about the cosmos at all to the degree that the motions in their brains imitate the motions of the divine bodies in the heavens.

A similar view, which, Fodor admits, might seem scandalous, is implicit in Fodor's "language of thought" doctrine, the view that a human being can only learn a natural language if they already possess an innate language that is more powerful than any natural language that they can ever learn (see epigraph above). First, Fodor here follows in the tradition of Plato's view in the Meno that a person is born in innate possession of all the knowledge that they can ever learn. ${ }^{66}$

The first thing that seems scandalous about Fodor's view is that it is supposed to explain how a humble human child, like newborn Carlos, can learn a natural language like Spanish. Fodor claims that Carlos can only learn Spanish because he already possesses an innate language, which he calls "Mentalese," 67 that can express anything about the world that can be expressed in Spanish, as well as anything that can be expressed by any natural language that Carlos can ever learn. The view that Carlos can only learn a natural language like Spanish because he was born possessing an innate mental language that he never learned and that is more powerful that any natural language that he could ever learn is, putting it mildly, somewhat unsatisfying.

That is supposed to be an explanation? One would hope that the theory that is supposed to provide the explanation is less controversial that the humble fact that is purports to explain. In Fodor's "language of thought" doctrine, this is reversed. For his "language of thought" doctrine requires one to endorse an extravagant theory about an enormously powerful innate mental language invoked to "explain" how a humble child learns to say "Sí mamá!"

65. See Fodor, The Language of Thought and Fodor, LOT 2.

66. Plato, Meno, 86a. On Plato's view that knowledge is innate, see Richard McDonough, "Plato's Doctrine of Moral Education," in Moral Perspectives and Moral Education, ed. Chong Kim Chong. Singapore: Singapore University Press, 1991: 63-83.

67. Fodor, Psychosemantics, 98, 107, 114-15. 
In fact, Fodor's "language of thought" doctrine implies the microcosmic doctrine. If one defines a "world" in terms of the set of all the possible facts that might obtain in that world, then the "language of thought" doctrine requires that a person is born with an innate representation any possible facts in their world, and all of the possible relations of these facts to each other, that they could ever conceivably learn to express in language. That is, Fodor's "language of thought" doctrine requires that a normal linguistically competent human being is born with an innate "mentalese" representation of their entire knowable world in all of its multifarious possibilities. But that is nothing other than the view that a normal newborn child innately possesses a microcosmic representation of their entire knowable cosmos! It is, indeed, remarkable the way the ancient Greek paradigms keep reappearing in entirely new, sometimes initially unrecognizable forms.

\section{The Cosmological Reading of Zettel (608)}

Philosophy ... must remain cosmology, and cannot become theology. Schopenhauer, The World as Will and as Representation, vol. II ${ }^{68}$

It is clear that Wittgenstein's Tractatus was influenced by Schopenhauer, ${ }^{69}$ but Schopenhauer's influence remains in Wittgenstein's Later Philosophy, though in a more diffuse way. For Schopenhauer's view that all philosophy remains cosmology offers a key to understanding Zettel (para. 608), with the proviso that Zettel (para. 608) only compares the genesis of language and thought with the genesis of the ancient cosmos but does not offer any literal cosmological theories to that effect. The first subsection of the present section argues that Plato's cosmology bears a certain similarity, up to a point, with the cosmological imagery in Zettel (para. 608). The second briefly argues that, in another respect, the view in Zettel (para. 608) is, in a deep sense, Hesiodic rather than Platonic.70 The third argues that there is also an important sense in which Zettel (para. 608) (and Wittgenstein's later philosophy generally) is profoundly Socratic rather than Platonic. In other words, the Platonic analogies explored in the previous section still hold up to a certain point, but a deeper analysis reveals that Wittgenstein's later philosophy is more profoundly Hesiodic and Socratic rather than Platonic per se.

68. Arthur Schopenhauer, The World as Will and as Representation, vol. II, trans. E.F.J. Payne (New York: Dover, 1966), 611-612.

69. Max Black, A Companion to Wittgenstein's 'Tractatus' (Ithaca: Cornell University Press, 1970): 308, 311, 367, 372, 377-78; Ray Monk, Ludwig Wittgenstein: The Duty of Genius (New York: Penguin, 1991), 18-19, 137, 142-144, 428.

70. The key to understanding Wittgenstein's Zettel (para. 608) is to recognize that it is a profoundly Hesiodic passage. 


\title{
The Platonic Cosmology and Zettel (608)
}

\begin{abstract}
Plato can never be considered a biologist, or a founding father of neuroscience; [but] he writes about the intellectual powers of the head and brain in a number of his dialogues. Wickens, A History of the Brain; From Stone Age Surgery to Modern Neuroscience ${ }^{71}$
\end{abstract}

It is shown in $\S \mathrm{V}$ above that the place for the basic modern program of mechanistic cognitive science is prepared in Plato's archetypal cosmological views by eliminating the final causes that Plato himself holds are actually the most fundamental causes. This leaves the material mechanical causes at the "chaotic" (mechanical) earthly center of the cosmos. Since the human being is, on Plato's microcosmic view, modelled on the cosmos, where the brain at the center of the spherical head corresponds to the earth at the center of the spherical cosmos, this means that the control center of the human being is a material mechanism, stripped of final causation, at the center of the human head.

Although this view can, in this sense, be found in Plato's cosmology, Plato does not himself propose anything like a cognitive science: Indeed, his reasons for rejecting cognitive science offers a key insight into the new paradigm that Wittgenstein suggests in Zettel (para. 608). Recall from above that Zettel (para. 608) does not, as the neurological interpretation claims, hold that language and thought may arise from chaos at the neural center. Rather, Zettel (para. 608) implicitly distinguishes between the neural center and the new center for language and thought identified in Wittgenstein's later philosophy, namely, the "Angelpunkt [center-point] of our real need" in "ordinary life." Thus, the point in Zettel (para. 608) is that language and thought may arise from the very different kind of "chaos," the chaos of human activities, that one finds in that everyday earthly "center-point of our real need." Since the "center-point of our real need" in ordinary life is external to the organism, this means that Wittgenstein in Zettel (para. 608), like Plato, holds that language and thought arise from what goes on at the periphery of the organism (even though Plato and Wittgenstein disagree greatly on the specific nature of that periphery). However, despite major disagreements about the nature of the periphery, Plato's cosmology states the archetypal version of the view that the primary determination of human matters is at the periphery of the material mechanical organism - not at its material mechanical neural center.

Just as Copernicus, in astronomy, reassigned the old center, the earth, to the periphery, and the old periphery, the sun, to the new center, Zettel (para. 608) reassigns the old view of the cognitive center, the brain, to the periphery, and the old view of the cognitive periphery, the sphere of human activities, to the new center. That is, Zettel (para. 608) can be profitably seen as making a broadly

71. Andrew Wickens, A History of the Brain; From Stone Age Surgery to Modern Neuroscience (Oxford and New York: Psychology Press, 2014), 18. 
"Copernican" move by suggesting that the human organism is, so to speak, centered in the world of human activities - not, as cognitive science holds, in its brain. But that is, roughly, what Heidegger means by saying that human being is "Being-in-the-world."72 Thus, whereas Plato held that the true determinants of human life are found in the heavens, Wittgenstein and Heidegger, in their distinctively $20^{\text {th }}$ century views, hold that human being is centered in the activities "in the world" towards which human beings comport themselves in ordinary life. Plato's views are more "metaphysical," while Wittgenstein's and Heidegger's are, so to speak, more "existential." Despite these significant differences, Plato paves the way for Wittgenstein's view in Zettel (para. 608) by producing a seminal ancient archetype that frees one from the idea that human intelligence is controlled by a material machine at the neural center. There is, however, one momentous difference between Plato's view and Wittgenstein's view in Zettel (para. 608).

Hesiod's Cosmology and Zettel (608)

How could anything originate out of its opposite? For example, truth out or error? ...

The things of highest value cannot be derived from this transitory, seductive, deceptive, paltry world, this turmoil of delusion and lust. Rather from the lap of Being, the hidden god, the "thing-in-itself" - there must be their basis, ... Nietzsche, Beyond Good and Evil ${ }^{73}$

Although there are certain similarities between Plato's and Wittgenstein's views about the peripheral function of the brain in human intelligence, there is one momentous difference between their views. Whereas Plato holds that, at the most fundamental level, the order in human life must be produced by a prior order (the Demiurge and the Forms that it uses as patterns), Hesiod holds that even the gods emerge out of the chaos. ${ }^{74}$ Thus, there is, for Hesiod, no prior Demiurge looking to the Forms to shape the primal chaos into a cosmos. Zettel (para. 608), in this respect, revives the Hesiodic paradigm that has been embraced only by a tiny minority of thinkers in the Western tradition..$^{75}$ For it is, apparently,

72. Heidegger, Being and Time: §’s 12-13. See note 37 above! The present author holds that Wittgenstein agrees, roughly, with Heidegger, that language is not a way that human beings, from inside the prison of their craniums, represent the world, but that language is a way human-beings dwell-in-a-world. Richard McDonough, "Heidegger's Ereignis and Wittgenstein on the Genesis of Language," Open Journal of Philosophy (2014): $\$ 4.2$

73. Friedrich Nietzsche, Beyond Good and Evil, trans. Walter Kaufmann (New York: Vintage Books, 1966), para. 1.

74. Lamberton, Introduction to Hesiod, 13.

75. Krell discusses the Hesiodic dimension of Heidegger. David Farrell Krell, Notes on Martin Heidegger's Nietzsche, vol. 2, in Nietzsche, vol. 1 \& 2, trans. David Farrell Krell (San Francisco: Harper San Francisco, 1991). See McDonough, “Heidegger's Ereignis, § 5. 
very difficult to conceptualize the Hesiodic idea that order can arise in the world that is not produced by a prior order. Jerry Fodor, to take one notable example, cannot understand it. For Fodor holds that the order in our public language must be the mere reflection of a prior order in the innate Mentalese mechanism in the head.

Bertrand Russell remarks that, "as philosophy [Plato's Timaeus] is unimportant" but, significantly, goes on to admit that its "account of creation as bringing order out of chaos is to be taken quite seriously." 76 The present argument is not that Plato's account of the creation of order out of chaos is true. The argument is that the Platonic view that order can only arises out of a prior order, and the Hesiodic view that order (and even the gods) can actually arise out of chaos, represent two fundamentally different archetypes for the human mind. In the West, the Platonic paradigm has dominated (even in non-Platonists). It remains, therefore, for rare thinkers like Nietzsche and Wittgenstein to revive this Hesiodic view that the order in the world arises out of "chaos" without the involvement of any pre-existing ordering principles whatsoever. Indeed, it is part of the importance of Zettel (para. 608) that it is a distinctive modern reincarnation, applied to language and thought, of the ancient Hesiodic view that order and meaning can arise, not from some prior order, not from some eternal God or eternal patterns, not some prior neural machine that has been "organized" by evolutionary processes, but from "chaos."

\section{Bringing Philosophy (and Human Language) "down to earth"}

[We] in a sense, bring the question "What is [linguistic] meaning?" down to earth. Wittgenstein, The Blue and Brown Books ${ }^{77}$

Although Wittgenstein in Zettel (para. 608) agrees with Plato's archetypal view that the brain is not the control center of the human organism, he does not agree with Plato's view that the true determinants of human existence lie at the divine celestial periphery of the cosmos. Rather, Wittgenstein's later philosophy brings philosophy, and, with it, language and thought, "down to earth." But this is the explicit reincarnation of Socrates' mission, as described by Cicero, to bring philosophy "down from the heavens to earth." 78 Just as Socrates was only

76. Bertrand Russell, A History of Western Philosophy (New York: Simon and Schuster, 1945), 143.

77. Wittgenstein, Blue and Brown Books, 1.

78. A.E. Taylor, Socrates (New York: Doubleday and Company, 1952), 138. See also Richard McDonough, "Wittgenstein in the Midst of Life, Death, Sanity, Madness - and Mathematics," in Stanley Cavell on Aesthetic Understanding, ed. Gary Hagberg (Cham, Switzerland: Palgrave Macmillan, 2018), § 5. See also Richard McDonough, “Wittgenstein's Rejection of the Queer," Graduate Faculty Philosophy Journal, (2020) [Forthcoming, Fall]. 
interested in what goes on in people's lives, rather than at the heavenly periphery of the cosmos, Wittgenstein's later philosophy is similarly only interested in what people can do in their lives: "The form of expression we use [when we are doing philosophy] seems to have been designed for a god ... For us [mere humans], of course, these forms of expression are like pontifical which me may put on, but cannot do much with ...."79 That is, whereas Plato and Wittgenstein agree that the brain is not the control center of the human organism, Plato's view invokes metaphysical and cosmological views that Wittgenstein cannot accept. Given Socrates' relative lack of interest in cosmology, ${ }^{80}$ in favor of a focused interest in human affairs on the imperfect "dim vast vale of tears," 81 the earth, Plato did not choose Socrates, but, rather, the $5^{\text {th }}$ century Pythagorean, Timaeus, to present the cosmology in the Timaeus. Thus, despite an abstract similarity with Plato's views at a certain level, Wittgenstein's later philosophy has a profoundly Socratic dimension. Indeed, there is, perhaps, no greater insight into the spirit of Wittgenstein's later philosophy than it is infused by the ancient Greek virtue, central to Socrates' argument in the Charmides, of sophrosyne, which involves "accepting the bounds which excellence lays down for human nature," refusing all "excess," including, of course, metaphysical excess. ${ }^{82}$ Similarly, Wittgenstein's later philosophy, respecting the limits of human existence, does not purport to plumb the metaphysical depths of the cosmos. This is why Zettel (para. 608) only compares the genesis of language to the genesis of the cosmos, but does not offer any theories to that effect. Since Zettel (para. 608) presents a picture of language and thought proportional to human abilities, the cosmological imagery in Zettel (para. 608) is, so to speak, "existential" rather than metaphysical.

\section{Summary}

Let us bear well in mind that both the theme of our question - "philosophy" - as well as the way in which we ask "what is that ..." are Greek in origin. We ourselves belong to this origin even when we do not mention the word "philosophy." Heidegger, What is Philosophy? ${ }^{83}$

In summary, there are three distinct ancient Greek archetypes at work in Zettel (para. 608), one Platonic, one Hesiodic, and one Socratic. First, although Plato's cosmology agrees that there is a neural machine in the cranium it disagrees with modern cognitive science that the ultimate causes, which for Plato are teleological rather than mechanical, are found in that neural control center in the

79. Wittgenstein, Philosophical Investigations, para. 426.

80. Plato, Phaedo, 97b-99d.

81. The expression is from Shelley's "Hymn to Intellectual Beauty."

82. Huntington and Cairns, Introduction to Plato's Charmides, 99.

83. Martin Heidegger, What is Philosophy? trans. Jean Wilde and William Kluback (New Haven: College and University Press, 1956), 39. 
head. Thus, Plato's cosmology provides the archetype of the sort of view that frees one from the dominance of the modern cognitive science view that the neural machine at the center of the cranium controls the human organism. However, Wittgenstein's later philosophy cannot agree with Plato's metaphysical views about the final causes at the cosmic periphery and, therefore, cannot agree with Plato's views about the ultimate causes of events in the human microcosm as well. Rather, in keeping with the more modest views of $20^{\text {th }}$ century philosophy, Wittgenstein's later philosophy holds that the human organism's language and thought is centered in the periphery of the organism, i.e., in the activities in Wittgenstein's "human all too human" 84 "forms of life," 85 not the Phaedo's sublime eternal unchanging "Form of life." 86 Wittgenstein's later philosophy holds that it is not in the synapses of the brain that thought and meaning are at "home," but, sozusagen, in the activities of everyday human life. ${ }^{87}$

The second ancient Greek archetype needed to understand Zettel (para. 608) is Hesiod's view that the order of the cosmos arises not out of a prior order but rather out of "chaos." Zettel (para. 608) belongs with that rare set of thinkers in the West, such as Nietzsche and Heidegger, who hold that order, like the orders of language and thought, do not need to be the mere repetition of some pre-existing order but actually arise out of "chaos." In Wittgenstein's later philosophy, however, the "chaos" is not cosmic chaos but the chaos of human activities in the "Angelpunkt of our real need" (the everyday arena of human activities).

The third Greek archetype needed to appreciate Zettel (para. 608) is Socrates' mission to bring philosophy down from the cosmic periphery to earth that Wittgenstein explicitly endorses on the first page of his Blue Book. ${ }^{88}$ Thus, the reference in Zettel (para. 608) to continuing further in the direction of the center is not a reference to continuing further toward the center of the brain, but is a Socratic call for the philosophies of language and mind to continue further in the direction of the relevant existential center of human life (the arena of human actions). The difference is only that whereas Socrates understood his task to bring every area of philosophy "down to earth," Wittgenstein's later philosophy undertakes this task specifically with regard to the philosophies of language and thought.

The claim is not that there are no major differences between Wittgenstein's later philosophy and these paradigms in ancient Greek philosophy. The point is rather that given all the enormous changes in philosophy between the time of the ancient Greeks and the advent of Wittgenstein's Later Philosophy in the $20^{\text {th }}$

84. The expression is from Friedrich Nietzsche, Human, All Too Human, trans. R.J. Hollingwood (Cambridge: Cambridge University Press, 1996).

85. Wittgenstein, Philosophical Investigations, 226

86. Plato, Phaedo, 106d.

87. Wittgenstein, Philosophical Investigations, para. 118

88. Wittgenstein, Blue Book, 1 
century, changes required by the Renaissance, Descartes' subjectivist revolution, the $18^{\text {th }}$ century Enlightenment, the development of $20^{\text {th }}$ century physics, ${ }^{89}$ the ancient Greek philosophies and literature continue, as Nietzsche pointed out, to provide the archetypes of philosophic thought.

\section{Trapped in a Paradigm}

The history of philosophy is the lingua franca which makes communication between philosopher's, at least of different points of view, possible. Philosophy without the history of philosophy, if not empty or blind is, at least, dumb. Wilfrid Sellars, Science and Metaphysics ${ }^{90}$

It is worth asking how commentators have managed to read various kinds of extravagant neurophysiological theories into Zettel (para. 608) when it is quite clear that such interpretations cannot be the correct reading of a passage in the philosopher whose signature view is that one must not advance any kind of theory. ${ }^{91}$ How can it be that virtually all scholars have managed to attribute such utterly un-Wittgensteinian views to a passage in Wittgenstein's later philosophy?

The answer is that, in a fashion made clear by Kuhn, ${ }^{92}$ scholars tend to presuppose their own paradigm when evaluating opposing paradigms - which guarantees that the alternative paradigm must either look absurd or like a version of their own paradigm. Thus, since virtually everybody (except a few outliers like Heidegger and Wittgenstein) think they know that the brain is the control center of the human organism, then, when Wittgenstein asks why must "the system [of neural impulses] continue further in the direction of the center?" it is assumed that surely he must be asking why the system of neural impulses must continue further in the direction of the neural center. What alternative center could it be? And when Zettel (para. 608) goes on to ask why the order of language and thought cannot "proceed, so to speak, out of chaos?" surely it must be asking why this order cannot proceed out of chaos in the brain! What alternative chaos could it be? That is, when, following the Copernican analogy, Zettel (para. 608) attempts to replace the dominant cognitive science paradigm's view about the center of the linguistic microcosm, i.e., the neural center, with a new paradigm that identifies a new center, i.e., the existential "Angelpunkt of our real need" in "ordinary life," the established cognitive science paradigm can only see this as just as absurd as Copernicus' new paradigm seemed to the defenders of the entrenched Ptolemaic paradigm. Kuhn describes the "reasons" the Ptolemaic paradigm gave to reject the new Copernican paradigm,

89. Whitehead, Process, 39.

90. Sellars, Wilfrid. Science and Metaphysics (London: Routledge \& Kegan Paul, 1968), 1.

91. Wittgenstein, Philosophical Investigations, para. 109.

92. Kuhn, The Structure of Scientific Revolutions, chap. 5. 
The earth is not part of the heavens; it is the platform from which we view the heavens. And the platform shares few or no significant characteristics with the celestial bodies seen from it. The heavenly bodies seem bright points of light, the earth an immense nonluminous sphere of mud and rock. Little change is observed in the heavens: ... In contrast, the earth is the home of birth and change and destruction. ... It seems absurd to make the earth like the heavenly bodies whose most prominent characteristic is that immutable regularity not to be achieved on the corruptible earth. ${ }^{93}$

That is, confronted with the new Copernican paradigm, defenders of the Ptolemaic paradigm simple rehearse their own paradigm, and feel justified in doing so, even though, to the Copernicans, they appear to be begging the question, because, for the defenders of the Ptolemaic paradigm, their own paradigm determines what makes sense for them and what does not. Similarly, since virtually everyone in the $20^{\text {th }}-21^{\text {st }}$ centuries thinks they know that the brain is the "platform" from which human beings view the world, it seems absurd to suggest that it is not the control center of the human organism. One can practically see that this is true (just as Ptolemy can see with his own eyes that the earth stands still while the heavens revolve around them). If one's brain is injured, one cannot think or speak properly, whereas an injury to one's hand or foot or stomach does not have the same devastating consequences for linguistic or cognitive ability. From cognitive scientists perspective, to deny that the brain is the control center of the human being seems as nonsensical as it seemed to be nonsensical to the defender of the Ptolemaic paradigm to deny that the earth is the center of the cosmos-but, for all that, the earth is not the center of the universe.

It should now be clear that the orthodox view that Zettel (para. 608) suggests some extravagant theory about neural processes is the result of reading it in the light of the very paradigm it is attacking. The present paper attempts to liberate one from this error, and show that Zettel (para. 608) is proposing Wittgenstein's own "Copernican Revolution" in the understanding of language and thought, ${ }^{94}$ by taking the reader back to certain archetypes in ancient Greek philosophy and literature. For the framework for cognitive science did not, so to speak, "fall from heaven." 95 It was developed by the philosophers of ancient Greece and passed, in ever new forms, down through the ages. The present paper attempts to show that the archetypes for the alternatives to the materialistic mechanistic cognitive science paradigm, one version of which is developed by Wittgenstein in Zettel

93. Thomas Kuhn, The Copernican Revolution: Planetary Astronomy in the Development of Western Thought (Cambridge, Mass: Harvard University Press, 1957), 43.

94. McDonough, "Towards a non-mechanistic," 18-21; McDonough, "A Culturalist Account", 281-286; Richard McDonough, "Wittgenstein's Critique of Mechanistic Atomism," Philosophical Investigations 14, no. 3 (1991): 246-251.

95. The expression is from Heidegger, Martin. "The Question Concerning Technology." The Question Concerning Technology and other essays (New York: Harper and Row, 1982) 
(para. 608), and Wittgenstein's later philosophy generally, were also developed in ancient Greek philosophy and literature.

\section{Bibliography}

Anscombe, Elizabeth. An Introduction to Wittgenstein's Tractatus. Philadelphia: University of Pennsylvania Press, 1971.

Ben-Yami, Hanoch. "The Hercules in the Machine: Why Block's Argument against Behaviorism is Unsound." Philosophical Psychology 18, no 2 (2005): 179-286.

Black, Max. A Companion to Wittgenstein's 'Tractatus'. Ithaca: Cornell University Press, 1970

Carone, Gabriela Roxana. Plato's Cosmology and its Ethical Dimensions. Cambridge: Cambridge University Press, 2005

Churchland, Patricia. Neurophilosophy. Cambridge: MIT Press, 1989

Churchland, Paul. A Neurocomputational Perspective: The Nature of Mind and the Structure of Science. Cambridge: MIT Press, 1989

Churchland, Paul. The Engine of Reason, the Seat of the Soul: A Philosophical Journey into the Brain. Cambridge: MIT, 1995

Cooper, John.(ed.) Plato: Complete Works. Indianapolis: Hackett, 1997.

Cornford, F.M. Plato's Cosmology. London: Routledge Kegan Paul, 1997.

Davies, Martin. "Concepts, Connectionism, and the Language of Thought." In Philosophy and Connectionist Theory, edited by Ramsey, Stich, Rummelhart. Hillsdale: Psychology Press, 1991.

Dilman, Ilham. Wittgenstein's Copernican Revolution: The Question of Linguistic Idealism. Basingstoke: Palgrave, 2002.

Fodor, Jerry. The Language of Thought Cambridge: Harvard, 1979.

Fodor, Jerry. Psychosemantics. Cambridge: MIT Press, 1987.

Fodor, Jerry. LOT 2. Oxford: Oxford University Press, 2020.

Goldberg, Bruce. "Mechanism and Meaning." In Knowledge and Mind: Philosophical Essays, edited by Carl Ginet and Sydney Shoemaker. Oxford: Oxford University Press, 1983.

Goldberg, Bruce. "Are Human Beings Mechanisms." Idealistic Studies, Special Issue. Wittgenstein and Cognitive Science, edited by Richard McDonough 29, no. 3 (1999): 139-152.

Green, Richard H. "Central State Materialism and Consciousness." Philosophy 56, no. 215 (1981): 106-113

Greenfield, Susan. Journey to the Centers of the Mind New York: W.H. Freeman and Co., 1995.

Hacker, Peter; and Bennett, Max. Philosophical Foundations of Neuroscience. Blackwell: Oxford, 2003.

Hark, Ter. "Electric Brain Fields and Memory Traces: Wittgenstein and Gestalt Psychology." Philosophical Investigations 18, no. 2 (1995): 113-138. 
Heidegger, Martin. What is Philosophy? Translated by Jean Wilde and William Kluback. New Haven: College and University Press, 1956.

Heidegger, Martin. Being and Time. Translated by John Macquarrie and Edward Robinson. San Francisco: HarperSanFrancisco, 1962.

Heidegger, Martin. "The Question Concerning Technology." The Question Concerning Technology and other essays. New York: Harper and Row, 1982.

Cairns, Huntington, Introduction to the Charmides. In Collected Dialogues of Plato. Edited by Edith Hamilton and Huntington Cairns. Princeton: Princeton University Press, 1969.

Ho, Edward Kei Sjhin and Chan, Kei Lan. "How to Design a Connectionist Holistic Parser." Neural Computation 11, no. 8 (1999): 1995-2016.

Krell, David Farrell. Notes on Martin Heidegger's Nietzsche, vol. 2. In Nietzsche, Vol. 1 \& 2. Translated by David Farrell Krell. San Francisco: Harper San Francisco, 1991.

Kuhn, Thomas. The Copernican Revolution: Planetary Astronomy in the Development of Western Thought. Cambridge: Harvard University Press, 1957.

Kuhn, Thomas. The Structure of Scientific Revolutions. Chicago: University of Chicago Press, 1970.

Malcolm, Norman. Memory and Mind. Ithaca: Cornell University Press, 1977.

Malcolm, Norman, and Armstrong, David. Consciousness and Causality: A Debate on the Nature of Mind. Oxford: Blackwell, 1984.

Malcolm, Norman. Nothing is Hidden. Oxford: Blackwell, 1986.

Malcolm, Norman. Wittgenstein: From a Religious Point of View? New York: Routledge, 1997.

Lamberton, Robert. Introduction to Hesiod: Works \& Days and Theogony. Indianapolis: Hackett, 1993.

McDonough, Richard. "Towards a non-Mechanistic Theory of Meaning." MIND. XCVIII No. 389 (1989): 1-21.

McDonough, Richard. "A Culturalist Account of Folk Psychology." In The Future of Folk Psychology, edited by John Greenwood. Cambridge: Cambridge University Press, 1991.

McDonough, Richard. "Plato's Not to Blame for Cognitive Science." Ancient Philosophy 11, no. 2 (1991): 301-314.

McDonough, Richard. "Wittgenstein's Critique of Mechanistic Atomism." Philosophical Investigations 14, no. 3 (1991): 246-251.

McDonough, Richard. "Plato's Doctrine of Moral Education." In Moral Perspectives and Moral Education, edited by Chong Kim Chong. Singapore: Singapore University Press, 1991, 63-83.

McDonough, Richard. "The Last Stand of Mechanism." Journal of Speculative Philosophy 6, no. 3 (1992): 206-25.

McDonough, Richard. "Wittgenstein's Reversal on the Language of Thought Doctrine." Philosophical Quarterly 44, no. 177 (1994): 482-494. 
McDonough, Richard. Review of Paul Churchland. The Engine of Reason, the Seat of the Soul. Metascience 7, no. 2 (1998): 374-380.

McDonough, Richard. "Wittgenstein and the Possibility of a Science of Man." Idealistic Studies, Special Issue. Wittgenstein and Cognitive Science, edited by Richard McDonough. 29, no. 3 (1999): 125-138

McDonough, Richard. "Bringing Cognitive Science Back to Life." Idealistic Studies, Special Issue. Wittgenstein and Cognitive Science, edited by Richard McDonough. 29, no. 3 (1999): 173-213.

McDonough, Richard. “Bringing Consciousness Back to Life." Metascience 9, no. 2 (2000): 238-245.

McDonough, Richard. "Wittgenstein, German Organicism, Chaos, and the Centre of Life." Journal of the History of Philosophy XLII, no. 3 (2004): 297-326.

McDonough, Richard. Martin Heidegger's Being and Time. New York: Peter Lang, 2006.

McDonough, Richard. “Wittgenstein's Augustinian Cosmogony in Zettel 608," Philosophy and Literature 39, no. 1 (2014): 87-106.

McDonough, Richard. "Heidegger's Ereignis and Wittgenstein on the Genesis of Language." Open Journal of Philosophy 4, no. 3 (2014): 416-431.

McDonough, Richard. "Wittgenstein's Zettel 608: An Analogy with Martin Buber." Iyyun 63, July (2014): 259-288.

McDonough, Richard. “Wittgenstein's Philosophy and Austrian Economics." Studies in the Sociology of Science 5, no. 4 (2014): 1-11.

McDonough, Richard. "Wittgenstein's Augustinian Cosmology in Zettel 608." Philosophy and Literature 39, no. 1 (2015): 87-106.

McDonough, Richard. "Philosophy in a Fallen Language: Wittgenstein, Goethe, Milton." Studies in Language and Literature. 10, no. 4 (2015b): 1-14.

McDonough, Richard. "Wittgenstein from a Religious Point of View?" Journal for the Study of Religions and Ideologies 15, no. 43 (2016): 3-27.

McDonough, Richard. "Plato's Cosmic Animal vs the Daoist Cosmic Plant." Journal for the Study of Religions and Ideologies 15, no. 45 (2016): 1-22. http://jsri.ro/ojs/index.php/jsri/article/view/804.

McDonough, Richard. "Organicism." Dictionary of the Philosophy of Mind (2016). https://sites.google.com/site/minddict/organicism.

McDonough, Richard. “A Gestalt Model of Zettel 608.” Idealistic Studies 46, no. 2 (2016): 163-82.

McDonough, Richard. “The Unspeakable Organicism in Wittgenstein's Tractatus.” Iyyun 66, no. 1 (2017): 1-17.

McDonough, Richard. "Wittgenstein's and Borges Labyrinth Imagery." The Athens Journal of Humanities and the Arts 5, no. 4. (2018): 425-445. https://www.ath ensjournals.gr/humanities/2018-5-4-3-McDonough.pdf.

McDonough, Richard. "A Music Model of Zettel 608: Haydn and Beethoven." The Journal of Music and Meaning 14 (2018): 21-40. http://www.musicandmeaning. net/articles/JMM14/RichardMcDonoughJMM14.pdf 
McDonough, Richard. "Putnam's Argument that the View that we are Brains-ina-vat is Self-refuting." Meta: Research in Hermeneutics, Phenomenology, and Practical Philosophy 10, no. 1 (2018): 149-159. http://www.metajournal.org// articles_pdf/149-159-mcdonough-meta-techno.pdf.

McDonough, Richard. "Wittgenstein's Rejection of the Queer". Graduate Faculty Philosophy Journal (2020) [Forthcoming, Fall].

McDonough, Richard. "Plato: Organicism." Internet Encyclopedia of Philosophy. http://www.iep.utm.edu/platoorg

McDonough, Richard. "Roy Wood Sellars." Internet Encyclopedia of Philosophy. http://www.iep.utm.edu/sella-rw.

McGinn, Colin. Wittgenstein on Meaning. Oxford: Blackwell, 1984

McGinn, Colin. "Can we solve the mind-body problem?" MIND 98, no. 391 (1989): 349-366.

Mills, Stephen. "Wittgenstein and Connectionism." Philosophy and Cognitive Science, edited by Christopher Hookway and Donald Peterson. Cambridge University Press, 1993.

Monk, Ray. Ludwig Wittgenstein: The Duty of Genius. New York: Penguin, 1991.

Nietzsche, Friedrich. Beyond Good and Evil. Translated by Walter Kaufmann. New York: Vintage Books, 1966.

Nietzsche, Friedrich. Philosophy in the Tragic Age of the Greeks. Translated by Marianne Cowan. Chicago: Henry Regnery, 1969.

Nietzsche, Friedrich. Human, All Too Human. Translated by R.J. Hollingwood. Cambridge: Cambridge University Press, 1996.

Plato. Phaedo. Translated Hugh Tredennick. The Collected Dialogues of Plato, edited by Edith Hamilton and Hamilton and Huntington Cairns. Princeton: Princeton University Press, 1969.

Plato. Charmides. Translated Benjamin Jowett. The Collected Dialogues of Plato, edited by Edith Hamilton and Hamilton and Huntington Cairns. Princeton: Princeton University Press, 1969.

Plato. Protagoras. Translated W.K.C. Guthrie. The Collected Dialogues of Plato, edited by Edith Hamilton and Hamilton and Huntington Cairns. Princeton: Princeton University Press, 1969.

Plato. Phaedrus. Translated by R. Hackforth. The Collected Dialogues of Plato, edited by Edith Hamilton and Hamilton and Huntington Cairns. Princeton: Princeton University Press, 1969.

Plato. Republic. Translated Paul Shorey. The Collected Dialogues of Plato, edited by Edith Hamilton and Hamilton and Huntington Cairns. Princeton: Princeton University Press, 1969.

Plato. Symposium. Translated Michael Joyce. The Collected Dialogues of Plato, edited by Edith Hamilton and Hamilton and Huntington Cairns. Princeton: Princeton University Press, 1969. 
Plato. Statesman. Translated J.B. Skemp. The Collected Dialogues of Plato, edited by Edith Hamilton and Hamilton and Huntington Cairns. Princeton: Princeton University Press, 1969.

Plato, Timaeus. Translated by Benjamin Jowett. The Collected Dialogues of Plato, edited by Edith Hamilton and Hamilton and Huntington Cairns. Princeton: Princeton University Press, 1969.

Plato. Laws. Translated by A.E. Taylor. The Collected Dialogues of Plato, edited by Edith Hamilton and Hamilton and Huntington Cairns. Princeton: Princeton University Press, 1969.

Plato. Epinomis. Translated by A.E. Taylor. The Collected Dialogues of Plato, edited by Edith Hamilton and Hamilton and Huntington Cairns. Princeton: Princeton University Press.

Port, Robert, and Van Gelder, Timothy. Mind as Motion: Explorations in the Dynamics of Cognition Cambridge: MIT, 1995.

Proudfoot, D. “On Wittgenstein on Cognitive Science. Philosophy 72, no. 280 (1997): 189-217.

Putnam, Hilary. Reason, Truth and History. Cambridge: Cambridge University Press, 1981.

Robinson, John Mansley. An Introduction to Early Greek Philosophy. Boston: Houghton Mifflin, 1968.

Russell, Bertrand. A History of Western Philosophy New York: Simon and Schuster, 1945.

Safranski, Rudgier. Martin Heidegger: Between Good and Evil. Translated by Edward Osers. Cambridge: Harvard University Press, 1999.

Scheer, Richard. “Wittgenstein's Indeterminism,” Philosophy 66, no. 255 (1991): 523.

Schopenhauer, Arthur. The World as Will and as Representation, vol. II. Translated by E.F.J. Payne. New York: Dover, 1966.

Sellars, Wilfrid. “The Soul as Craftsman.” In Philosophical Perspectives. Springfield: Charles C. Thomas Publisher, 1967.

Sellars, Wilfrid. Science and Metaphysics. London: Routledge \& Kegan Paul, 1968.

Shelley, Percy Bysshe. "Hymn to Intellectual Beauty." The Selected Poetry and Prose of Shelley. Hertsfordshire: Wordsworth Publishing, 1994.

Silverman, Allen. "Plato's Middle Period Metaphysics and Epistemology." Stanford Encyclopedia of Philosophy (2014). https://plato.stanford.edu/entries/ plato-metaphysics/.

Stich, Steven. From Folk Psychology to Cognitive Science: The Case Against Belief. Cambridge, Mass: MIT Press.

Stillings, Neil; Chase, Christopher; and Feinstein, Mark. Cognitive Science: An Introduction Cambridge: MIT Press, 1995.

Sutton, John. "Remembering as Public Practice: Wittgenstein, Memory, and Distributed Cognitive Ecologies." Mind, Language and Action, edited by V.A. Munz and A. Coliva. Kirchberg am Wechsel, 2014. 
Taylor, A.E. Socrates. New York: Doubleday and Company, 1952.

Traupman, John. German \& English Dictionary. New York: Bantam Books, 1991.

Vlastos, Gregory. "The Disorderly Motion of the Timaeus." In Studies in Plato's Metaphysics, edited by R.E. Allen. London: Routledge and Kegal Paul, 1968.

Vlastos, Gregory. Plato's Universe. Seattle: University of Washington Press, 1975.

Whitehead, A.N. Process and Reality: An Essay in Cosmology (corrected edition) New York: Free Press, 1978.

Wickens, Andrew. A History of the Brain; From Stone Age Surgery to Modern Neuroscience. Oxford and New York: Psychology Press, 2014.

Wittgenstein, Ludwig. Philosophical Investigations $2^{\text {nd }}$ edition. Translated by G.E.M. Anscombe. Oxford: Blackwell, 1958.

Wittgenstein, Ludwig. The Blue and Brown Books. New York: Harper, 1965.

Wittgenstein, Ludwig. On Certainty. Translated by Denis Paul and G.E.M. Anscombe. Oxford: Blackwell, 1969.

Wittgenstein, Ludwig. Zettel. Translated by G.E.M. Anscombe. Berkeley: University of California Press, 1970.

Wittgenstein, Ludwig. Remarks on the Foundations of Mathematics. Translated by G.E.M. Anscombe. Cambridge: MIT Press, 1972.

Wittgenstein, Ludwig. Culture and Value. Translated by Peter Winch. Chicago: University of Chicago, 1980. 